Group $A$. The address of both honorary secretaries is, the British Conference on Automation and Computation, c/o Institution of Electrical Engineering, Savoy Place, London, W.C.2.

\section{Post Office Engineering-Apprenticeship Scheme}

IT was announced in Parliament by Miss Mervyn Pike, Assistant Postmaster General, that the Post Office is engaged in an expanding nation-wide programme of mechanization and automation. To enable it to carry this through, men will be required to train for key engineering-posts. A scheme is being launched under which university training or a diploma in technology course at a college of advanced technology will be guaranteed to about twenty students. During the student apprenticeship, including the time of attendance at university or college, salaries will be paid according to age, and varying from $£ 270$ per annum at seventeen to $£ 430$ at twenty-one and over. Student apprentices will be selected from young men of British nationality who are between the ages of seventeen and twenty on June 1 in the year when apprenticeship starts. The university or college studies will start in September/ October of the year after apprenticeship begins. The student apprenticeship will last $4 \frac{1}{2}$ years, except in Scotland and Northern Ireland, where it will be slightly longer to allow for the duration of university courses. Further information can be obtained from the Engineering Chief (O.51), Post Office Engineering Department, 2-12 Gresham Street, London, E.C.2. Applications for 1960 must be submitted by February 26.

National Science Foundation : Science Faculty and Senior Postdoctoral Fellowship Awards for 1960

The National Science Foundation has awarded 285 Science Faculty Fellowships in the sciences for the fiscal year 1960. These fellowships are offered as a means of improving the teaching of science, mathematics and engineering in American colleges and universities, and their primary purpose is to provide an opportunity for college and university science teachers to improve their work as teachers. Candidates must have a first degree or its equivalent, demonstrated ability and special aptitude for science teaching and advanced training, and three years of full-time science teaching at the college-level. There were 762 applicants from all parts of the United. States and its territories.

The Foundation has also announced the award of 75 Senior Postdoctoral Fellowships in the sciences for the fiscal year 1960, selected from 259 applicants. These Fellowships were awarded to scientists of demonstrated ability and special aptitude for productive scholarship in the sciences. Twenty-eight awards were made in the life sciences, and forty-seven in tho physical sciences.

\section{High Mach Number Air-breathing Machines}

The Combustion and Propulsion Panel of the Advisory Group for Aeronautical Research and Development, North Atlantic Treaty Organization, will hold its fourth colloquium in Milan during April 4-9. The meeting will be devoted to discussions on "High Mach Number Air-breathing Engines". The opening session will consist of a round-table discussion on "The Future of Air-breathing Engines". Invited papers from Germany, Italy, the United Kingdom and the United States will deal with: (1) performance and applications, (2) hypersonic inlet studies, (3) supersonic combustion and detonation, (4) nozzle flow with chemical reactions, (5) rotating machinery, and (6) high-temperature material problems. Although the meeting is unclassified from a security point of view, attendance is limited to those who are authorized to attend by either the Group national delegates, or by members of the Combustion and Propulsion Panel.

\section{Ford Foundation Grant to Cern}

THE European Organization for Nuclear Research has received from the Ford Foundation a grant amounting to five hundred thousand dollars to cover a period of four years. The facilities available at Cern now consist of two big particle accelerators, a $600 \mathrm{MeV}$. synchrocyclotion and a 28,000 MeV. proton synchrotron. The latter, the most powerful of its type in the world, has recently started operating with outstanding success. This grant follows a previous one of four hundred thousand dollars contributed by the Foundation in 1956 to cover similar expenses during four years.

\section{Announcements}

IT is announced that Cornelius Lanezos, senior professor in the School of Theoretical Physies at Dublin Institute for Advanced Studies, has recently been awarded the Chauvenet Prize by the Mathematical Association of America for an article entitled "General Theory of Linear Differential Operators". This article is to form the last chapter of a book which is to be published by Van Nostrand, entitled "Linear Differential Operators", by Prof. Lanczos.

MR. P. N. HARVEY has been appointed farm director at Gleadthorpe Experimental Husbandry Farm, Notts., of the Ministry of Agriculture, Fisheries and Food, in succession to Mr. P. J. Jones, who has been transferred to Bridget's Experimental Husbandry Farm.

Prof. Miohael Polanyi, emeritus professor of social studies in the University of Manchester, will give the 1960 Eddington Memorial Lecture in Cam. bridge at the Arts School Lecture Theatre, Bene't Street, on February 16, at 5 p.m. The title of his lecture is "Beyond Nihilism".

The MeCrone Associates of the United States are sponsoring a National Microscopy Symposium which will be held at the Del Prado Hotel in Chicago during June 13-15. The Symposium will cover (1) Instrumentation, (2) Methods and Techniques, and (3) Applications. Further information can be obtained from Walter C. McCrone Associates, 501 East 32nd Street, Chicago 16, Illinois.

Nos. 7, 8 and 9 of the Bibliography of Scientific Publications of South and South-East Asia, for July, August and September 1959, respectively, compiled jointly by Unesco Science Co-operation Offices for South and South-East Asia and published by Insdoc, National Physical Laboratory, New Delhi, contain a further 1,660 classified entries, together with author index, and the August issue includes also the Index to Vol. 4 (1958).

ERratum. In the communication entitled "Isolation of 2-Aminoethane Phosphonic Acid from Rumen Protozoa", by M. Horiguchi and M. Kandatsu, in Nature of September 19, p. 901, Fig. 1 has unfortunately been inverted. 